\title{
PETROGRAFIA E MICROESTRUTURAS DE TECTONITOS DA ZONA DE CISALHAMENTO RIBEIRA, VALE DO RIBEIRA, SP E PR: IMPLICAÇÕES NO ZONEAMENTO METAMÓRFICO E ESTRUTURAL DO SUPERGRUPO AÇUNGUI E UNIDADES CORRELATAS
}

\author{
FREDERICO MEIRA FALEIROS' \& GINALDO ADEMAR DA CRUZ CAMPANHA ${ }^{2}$
}

\begin{abstract}
PETROGRAPHYAND MICROSTRUCTURES OF THERIBEIRA SHEAR ZONE TECTONITES, RIBEIRA VALLEY, SEBRAZIL: IMPLICATIONS IN THE METAMORPHIC AND STRUCTURAL ZONING OF THE AÇUNGUI SUPERGROUP AND CORRELATED UNITS The Ribeira Shear Zone, in the homonymous valley, Southeastern Brazil, is a dextral transcurrent, eastnortheast trending structure that cuts metasedimentary and metabasics rocks of the Açungui Supergroup and granitic plutons. Petrographic and microstructural data indicate a long deformational history of the shear zone that is characterized by mylonites formed under amphibolite $\left(550^{\circ}-600^{\circ} \mathrm{C}\right)$ to greenschist $\left(300^{\circ}-400^{\circ} \mathrm{C}\right)$ facies conditions, followed by formation of breccias. A clearly spatial distribution of the mylonites of different metamorphic degrees indicate that the Ribeira Shear Zone had a fundamental role in the metamorphic and structural zoning of part of the Açungui Supergroup and correlated units. A vertical displacement about 3,5-4,4 $\mathrm{km}$ is inferred between the neighboring tectonic blocks.
\end{abstract}

Keywords: Shear zones, microstructures, metamorphism, Açungui Supergroup.

\begin{abstract}
Resumo A Zona de Cisalhamento Ribeira, situada no vale homônimo, Estados de São Paulo e Paraná, é uma estrutura transcorrente destral de direção geral leste-nordeste que corta rochas metassedimentares e metabásicas do Supergrupo Açungui, além de corpos graníticos nele intrusivos. Dados petrográficos e microestruturais indicam uma longa história deformacional da zona de cisalhamento. Esta se caracteriza por milonitos formados em condições desde fácies anfibolito, a $550^{\circ}-600^{\circ} \mathrm{C}$, até xisto verde, a $300^{\circ}-400^{\circ} \mathrm{C}$, seguidos pela geração de brechas. A nítida variação espacial dos milonitos de diferentes graus metamórficos indica que a Zona de Cisalhamento Ribeira teve papel fundamental no zoneamento metamórfico e estrutural de parte do Supergrupo Açungui e unidades correlatas, sendo responsível por um deslocamento vertical de cerca de 3,5-4,4 km entre os blocos tectônicos que limita.
\end{abstract}

Palavras-chave: Zonas de cisalhamento, microestruturas, metamorfismo, Supergrupo Açungui.

INTRODUÇÃO A Zona de Cisalhamento Ribeira, localizada na região do vale homônimo, $\mathrm{SP}$ e $\mathrm{PR}$, se isere no importante sistema de cisalhamento de direção leste-nordeste que corta rochas précambrianas nas regiões sudeste e sul do Brasil. Possui notável expressão em imagens de sensores remotos e fotografias aéreas, infletindo as estruturas regionais por quilômetros a dezenas de quilômetros. Secciona rochas metamórficas do Supergrupo Açungui (Campanha 1991, Campanha \& Sadowski 1999) e granitóides nele intrusivos. Em sua extremidade leste une-se com a Zona de Cisalhamento Lancinha, que por sua vez liga-se com a Zona de Cisalhamento de Cubatão-Além Paraíba, tida como um dos principais limites crustais de toda a Faixa Ribeira. Na sua extremidade oeste une-se com a Zona de Cisalhamento de Morro Agudo, que apresenta direção norte-nordeste, passando a ter essa denominação no Estado do Paraná (Fig. 1).

Apesar da grande expressão regional, a Zona de Cisalhamento Ribeira é de difícil caracterização em campo, principalmente quando corta rochas metassedimentares de baixo grau. Quando afeta rochas mais competentes, tais como anfibolito, quartzito e granitóides, desenvolve rochas miloníticas e cataclásticas.

A idade mínima de ativação da Zona de Cisalhamento Ribeira é de $626 \mathrm{Ma}$, dado esse obtido por isócrona Rb-Sr em rocha total para rochas graníticas do Maciço Itaoca (Mello 1995, Mello \& Bettencourt 1998).

CONTEXTO GEOLÓGICO REGIONAL As rochas deformadas pela Zona de Cisalhamento Ribeira pertencem a três unidades principais: subgrupos Ribeira e Lajeado, que são subunidades do Supergrupo Açungui segundo Campanha (1991) e Campanha \& Sadowski (1999), e Seqüência Serra das Andorinhas (Campanha et al. 1985, 1986).

O Subgrupo Lajeado ocorre em uma cunha tectônica limitada pelas zonas de cisalhamento Ribeira, Figueira e Quarenta-Oitava (Fig. 2), sendo constituído por sete formações alternadamente siliciclástica e carbonática sobrepostas, com estruturas primárias preservadas (Campanha 1991, Campanha \& Sadowski 1999). A macroestrutura do Subgrupo Lajeado é caracterizada por grandes anticlinais e sinclinais abertos com eixos subhorizontais de direção nordeste e clivagem plano-axial com alto mergulho para noroeste (Campanha \& Sadowski 2002). Em sua porção inferior o Subgrupo Lajeado é intrudido pelo Maciço de Itaoca (Mello 1995, Mello \& Bettencourt 1998), cuja faixa afetada pela Zona de Cisalhamento

\footnotetext{
I - Programa de Pós-Graduação em Geoquímica e Geotectônica, Instituto de Geociências da Universidade de São Paulo, Rua do Lago 562, CEP 05508-900, São Paulo, SP.

2 - Instituto de Geociências da Universidade de São Paulo, Departamento de Mineralogia e Geotectônica, Rua do Lago 562, CEP 05508-900, São Paulo, SP. E-mail: ffalci@usp.br, ginaldo@usp.br
} 


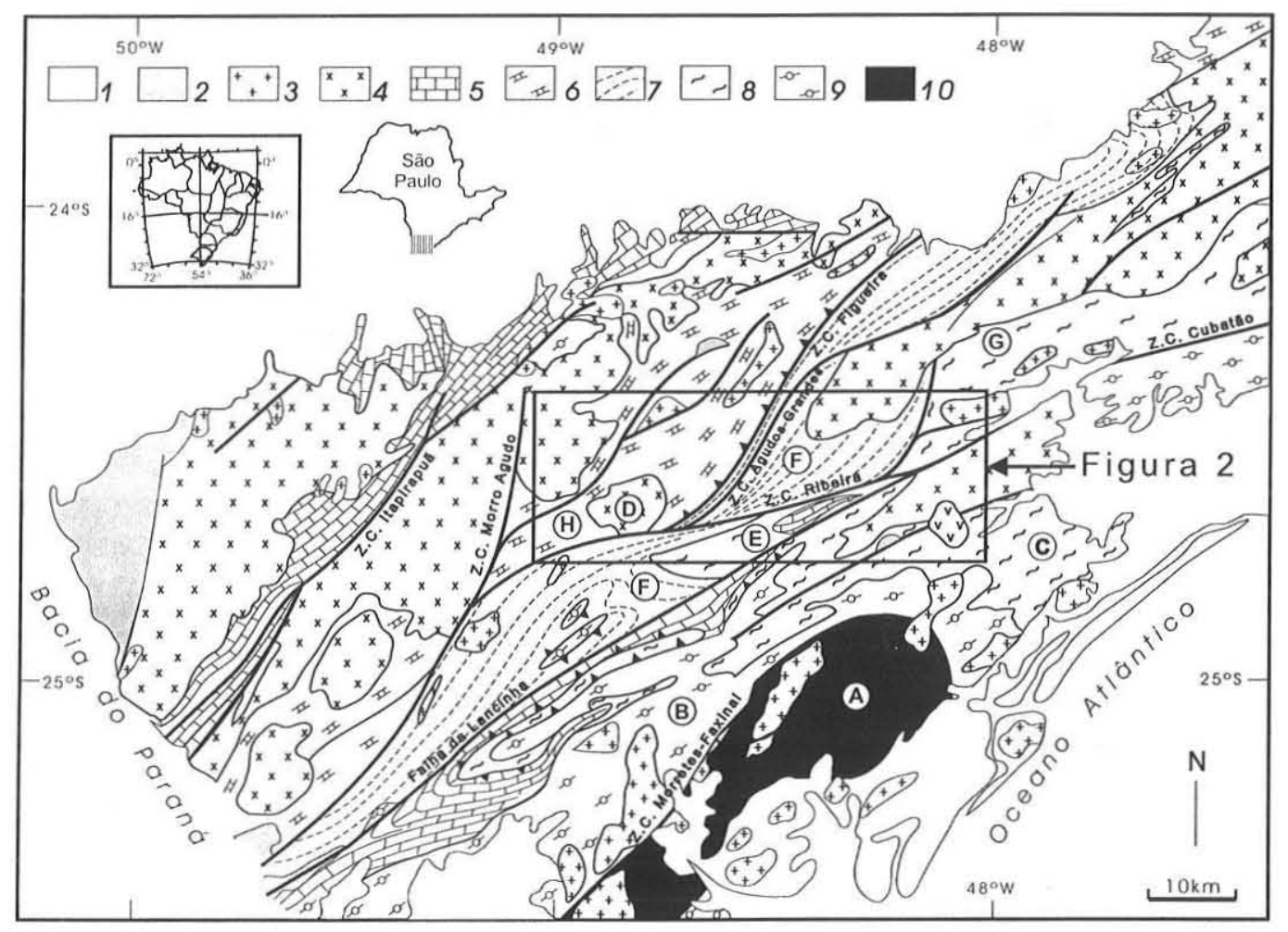

Figura 1 - Mapa tectônico do Domínio Apiaí da Faixa Ribeira (adaptado de Campanha \& Sadowski 1999). Principais domínios tectônicos e paleogeográficos: 1) coberturas e rochas intrusivas fanerozóicas, 2) molassas tardias cambrianas a neoprotezóicas, 3) granitos pós-tectônicos cambrianos a neoproterozóicos, 4) granitos sin-tectônicos neoproterozóicos, 5) plataformas carbonáticas proximais meso a neoproterozóicas, 6) plataformas carbonáticas distais meso a neoproterozóicas, 7) sequiências metaturbidíticas, metavulcânicas e metapelágicas meso a neoproterozóicas, 8) xistos de ambientes desconhecidos, 9) gnaisses migmatíticos meso a paleoproterozóicos. 10) grabronoritos e charnoquitos arqueanos. Principais unidades litoestratigráficas: A) Complexo Serra Negra, B) Complexo Gnáissico-Migmatítico, C) Seqüiência Turvo-Cajati, D) Maciço Itaoca, E) Seqüiência Serra das Andorinhas, F) Subgrupo Ribeira, G) Complexo Embu, H) Subgrupo Lajeado.

Ribeira compreende anfibólio-biotita monzogranito porfirítico protomilonitizado.

O Subgrupo Ribeira, que se separa do Subgrupo Lajeado pelas zonas de cisalhamento Figueira e Ribeira (Fig. 2), é constituído predominantemente por metarritmitos de granulação fina a muito fina, com intercalações subordinadas de metabasito, metarenito, metaconglomerado oligomítico, lâminas de metachert, metamarga, metacalcárioe formações ferríferas (Campanha 1991, Campanha \& Sadowski 1999). As estruturas desta unidade demonstram deformação mais intensa, com dobramento fechado a isoclinal e transposição do acamamento sedimentar para posição da clivagem ardosiana, que apresenta mergulho forte para noroeste (Campanha 1991).

As rochas da Sequiência Serra das Andorinhas, que ocorre na porção leste do bloco a sul da Zona de Cisalhamento Ribeira (Fig. 2), consistem de xisto fino carbonático, quartzo xisto, quartzito, mármore e subordinadamente metabasito. Predominam rochas com xistosidade bem desenvolvida, geralmente com laminação diferenciada onde alternam-se leitos ricos em quartzo e leitos ricos em mica. Esta unidade diferencia-se do Subgrupo Ribeira em termos de associação de protolitos, de modo que a primeira é uma associação tipicamente de natureza clástico-terrígena, enquanto a segunda é uma associação metavulcanossedimentar com expressiva contribuição de rochas metavulcânicas básicas
(Campanha 1991).

A Zona de Cisalhamento Ribeira tem um papel importante no zoneamento metamórfico e estrutural das unidades metassedimentares da região (Faleiros 2003), de maneira que separa um bloco a norte (onde ocorrem rochas metassedimentares com acamamento primário preservado, metamorfizadas na fácies xisto verde, zona da clorita), de um bloco a sul (onde as rochas estão metamorfizadas entre a zona da granada e a fácies anfibolito inferior e apresentam estruturas sedimentares totalmente transpostas; Faleiros 2003).

GEOMETRIA ECINEMÁTICA AZonadeCisalhamento Ribeira apresenta um traçado geral pouco variável onde trechos de orientação em torno de $\mathrm{N} 85^{\circ} \mathrm{E}$ se alternam com trechos $\mathrm{N} 75^{\circ} \mathrm{E}$ (Fig. 2). Exceção a esse padrão ocorre em sua extremidade oeste, na zona de junção com a Zona de Cisalhamento Morro Agudo, onde ocorre uma inflexão para direção $\mathrm{N} 60^{\circ} \mathrm{E}$.

A foliação milonítica associada à Zona de Cisalhamento Ribeira apresenta atitude pouco variável, em torno de $\mathrm{N} 75^{\circ}-85^{\circ} \mathrm{E}$ e mergulhos subverticais ora para noroeste ora para sudeste (Fig. 3a). A foliação média obtida mergulha $83^{\circ}$ para o azimute $343^{\circ}$ (Fig. 3a). O padrão da lineação de estiramento é mais complexo, visto que apesar do predomínio de lineações subhorizontais, não são raras lineações oblíquas e de máximo caimento (Fig. 3b). 


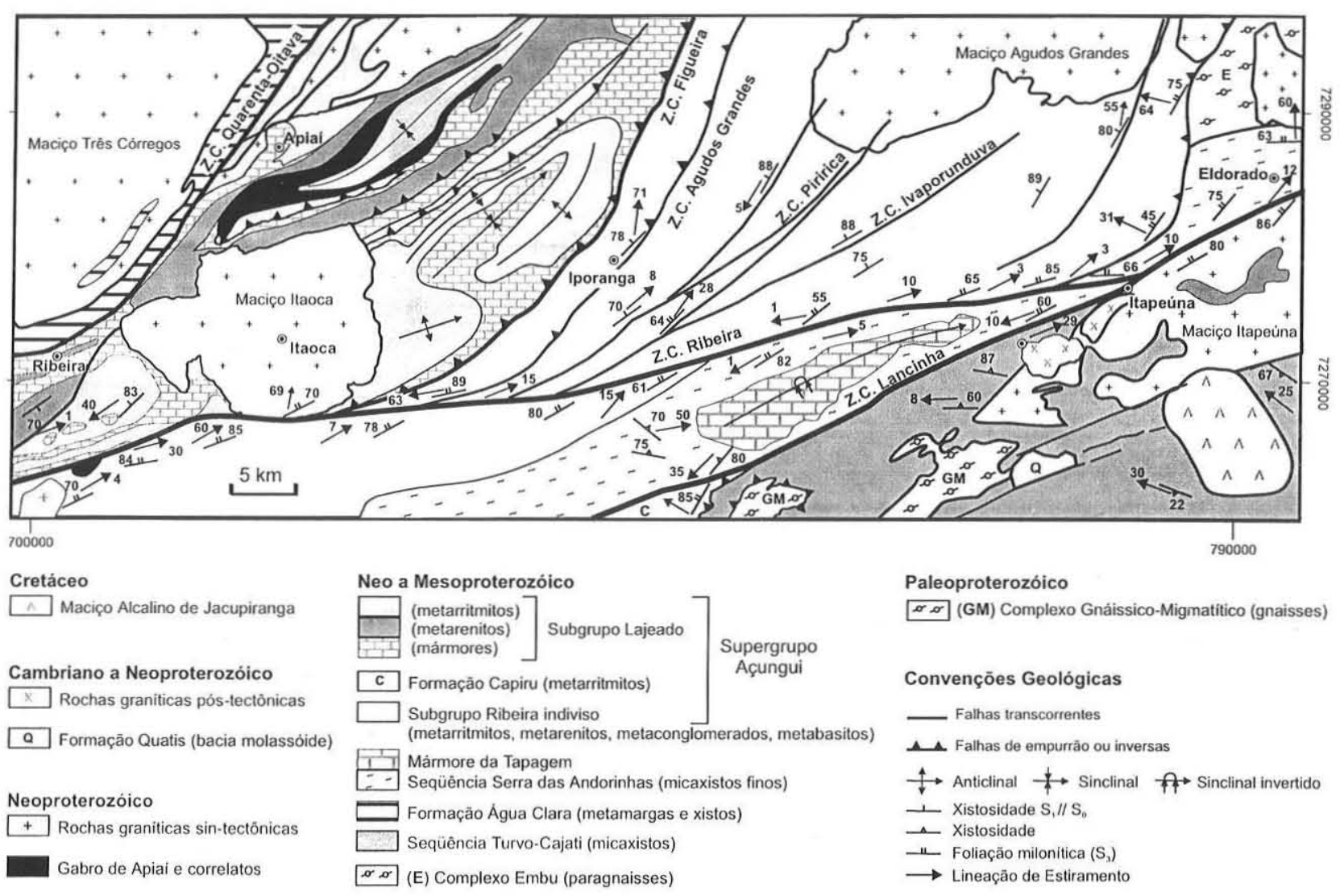

Figura 2 - Mapa geológico da área estudada segundo Faleiros (2003). Ver localização na figura 1.

Diversos indicadores cinemáticos nas escalas macroscópica (inflexão regional das estruturas - Figs. 1,2,9), mesoscópica (e.g. boudins e fragmentos rotacionados) e microscópica (e.g. porfiroclastos rotacionados ou estirados, micafish, pares de foliações SC) indicam sistematicamente movimentação destral. Exemplos de indicadores cinemáticos são mostrados na figura 4.

\section{MILONITOS E CATACLASITOS Características macroscópicas No campo a Zona de Cisalhamento Ribeira caracteriza-se por um domínio de rochas cisalhadas com espessura entre 500 e 1000 metros, onde ocorrem faixas de filonito (Fig. 5a), brecha (Fig. 5b), protomilonito, milonito e ultramilonito. Uma característica importante é a existência, lado a lado, de rochas de falha com texturas contrastantes (e.g. brecha e ultramilonito), que poderiam refletir diferentes estágios de movimentação da zona de cisalhamento em níveis crustais cada vez mais rasos. Alternativamente, a pressão de fluidos elevada pode ter induzido a formação de brecha no ambiente metamórfico dúctil (fraturamento hidráulico). Isto é sugerido pela presença de brecha tectônica no interior de boudins envoltos por faixas miloníticas (que em outra interpretação indicaria que o brechamento é anterior à milonitização), além de brecha cortada por veios de quartzo em várias direçôes (Fig. 5d). Adicionalmente, Faleiros et al. (em preparação) demonstram, pela análise de inclusões fluidas, que veios de quartzo sin-tectônicos à zona de cisalhamento foram gerados sob forte flutuação de pressão (pressão de aprisionamento de inclusões fluidas variando desde valores próximos da pressão litostática até abaixo da pressão hidrostática), como resultado de}

fraturamento hidráulico.

Quanto aos litotipos afetados pela Zona de Cisalhamento Ribeira predominam filito e xisto fino pertencentes ao Subgrupo Ribeira e à Sequiência Serra das Andorinhas, além de intercalações de anfibolito, quartzito, rochas calciossilicáticas, metaconglomerado e intrusões graníticas variadas.

$\mathrm{Na}$ faixa norte da zona de cisalhamento ocorrem corpos de filito cinzento a esverdeado, quando não alterado, constituído principalmente por sericita, quartzo, carbonato e clorita. Feições de cisalhamento, apesar de muito difícil reconhecimento, são ressaltadas quando estão presentes grandes quantidades de vênulas e veios de quartzo estirados e boudinados dentro da foliação, pela forte transposição de estruturas primárias (Fig. 5c) e pela presença de foliações SC e dobras intrafoliais. Estruturas observadas com menor frequiência compreendem kink bands com eixos subverticais, sistematicamente indicativas de rotação destral.

É importante destacar que fora das faixas cisalhadas a presença de veios de quartzo torna-se muito rara, indicando que estes estão intimamente relacionados com a zona de cisalhamento.

Lineação de estiramento marcante pode ocorrer em quartzo xisto e quartzito. Contudo, em geral, quando existem lineações nos litotipos mais micáceos, de maior ocorrência, torna-se muito difícil separar aquelas relacionadas com estiramento da lineação de interseção entre foliação e crenulação. Nesses casos, a lineação de estiramento pode ser melhor observada em paredes de veios de quartzo e camadas de metachert.

Na porção a sul da Zona de Cisalhamento Ribeira as rochas apresentam grau metamórfico mais elevado. Predomina xisto com- 

metamórfico e estrutural do Supergrupo Açungui e unidades correlatas
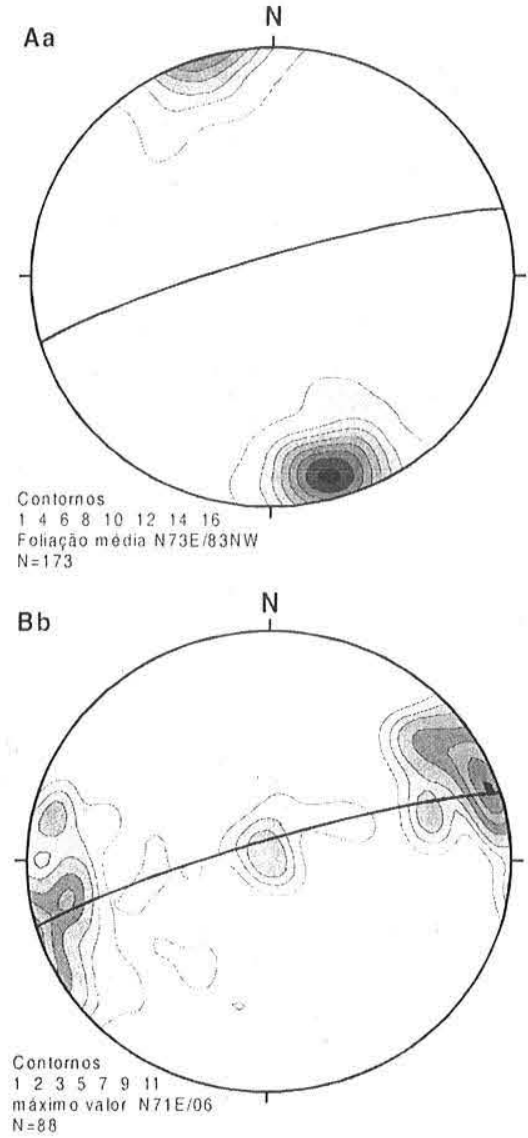

Figura 3 - Diagramas de Schmidt-Lambert, semi-esfera inferior contendo linhas de isofrequiência de pólos da foliação milonítica (a) e atitudes da lineação de estiramento (b).

posto por muscovita, quartzo, biotita e granada, com intensa lineação mineral de muscovita e biotita, e uma laminação formada pela segregação metamórfica entre leitos quartzosos e micáceos.

Corpos alongados de anfibolito verde escuro, concordantes com a foliação, ocorrem tanto no interior da zona de cisalhamento como a sul desta. Possuem largura, geralmente, de dezenas a centenas de metros, apesar de localmente ocorrerem corpos de espessura decimétrica a submétrica. De maneira geral, apresentam lineação mais desenvolvida que foliação, caracterizando tectonitos do tipo L.

De todas as rochas descritas, as graníticas são as que apresentam feições mesoscópicas de cisalhamento mais nítidas, tais como estrutura brechada, foliação lenticularizada, lineação de estiramento e porfiroclastos rotacionados. Predominam faixas de protomilonito com estrutura definida por porfiroclastos de feldspato e quartzo com formas arredondadas a angulosas, envoltos por uma matriz fina constituída por quartzo, muscovita e por vezes estilpnomelano e biotita.

As rochas da porção sul do Maciço de Itaoca são monzograníticas, apresentam texturas porfiríticas e estruturas foliadas. São formadas essencialmente por feldspatos, quartzo, biotita e hornblenda. Os feldspatos são róseos e suas dimensões variam de subcentimétricas a até $2 \mathrm{~cm}$. Esses cristais apresentam uma orientação preferencial de forma bem definida, mas geralmente mostram deformação em estado sólido incipiente. Biotita e
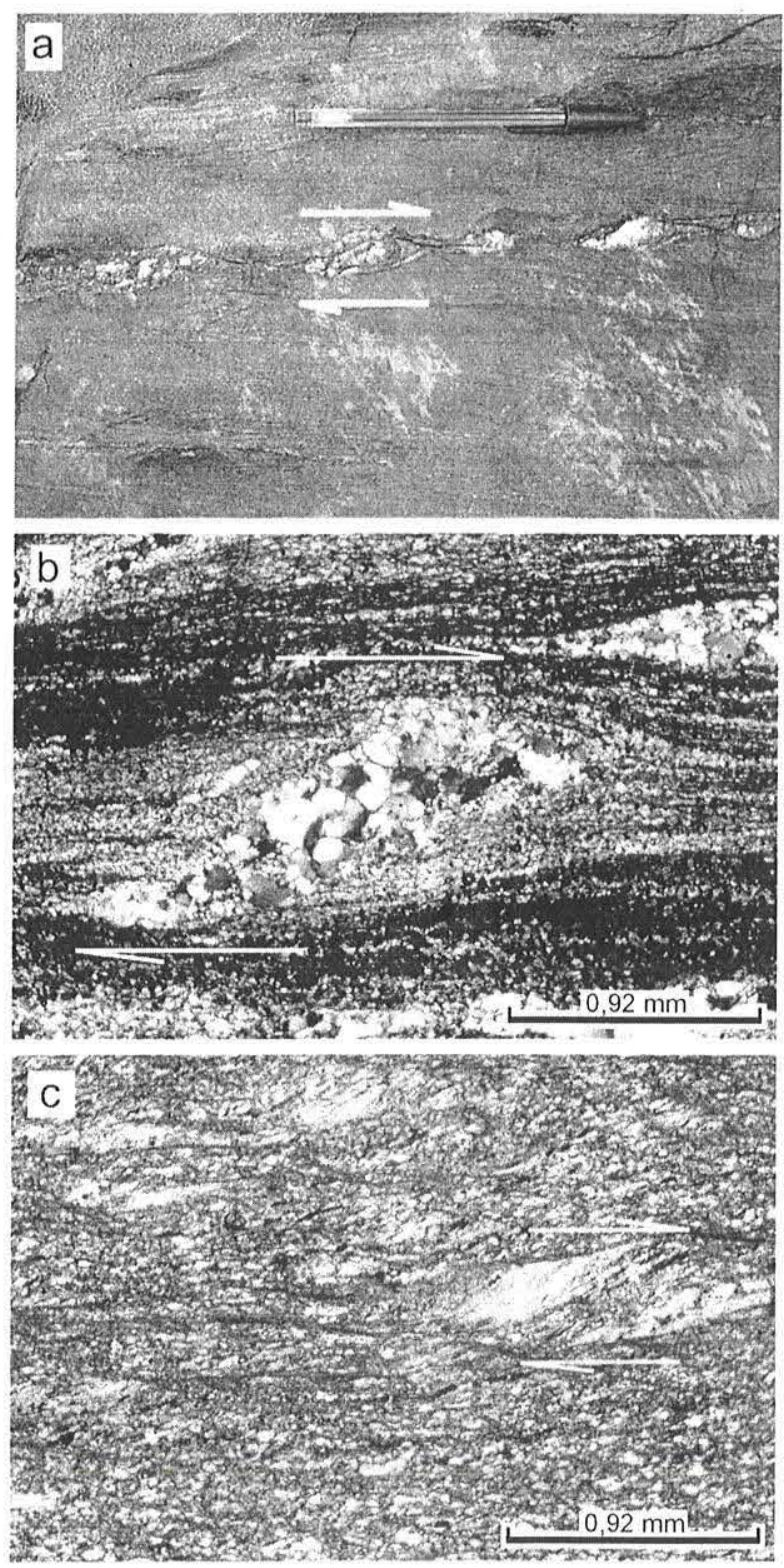

Figura 4 - Indicadores cinemáticos: (a) boudin de veio deformado, (b) porfiroclasto estirado,( c) par de foliações SC.

hornblenda são muito finas e seus agregados formam lentes alongadas de espessuras milimétricas entre os cristais de feldspato. O quartzo pode ser anédrico, subédrico ou em forma de ribbons. Raramente encontra-se estirado concordantemente com a foliação, ou recristalizado dinamicamente. Essa situação sugere que o corpo ígneo é tardi-deformacional em relação à Zona de Cisalhamento Ribeira.

Na faixa de mais intensa deformação ocorrem diversos xenólitos de rochas metassedimentares fortemente milonitizadas. Esses xenólitos são lenticulares ou tabulares e paralelos à foliação, conferindo um aspecto semelhante a gnaisse. Consistem de corpos de quartzito, biotita-quartzo xisto e sericita-quartzo xisto, geralmente com intensa lineação de estiramento. Nessas localidades o monzogranito apresenta faixas decimétricas de milonito, onde ocor- 

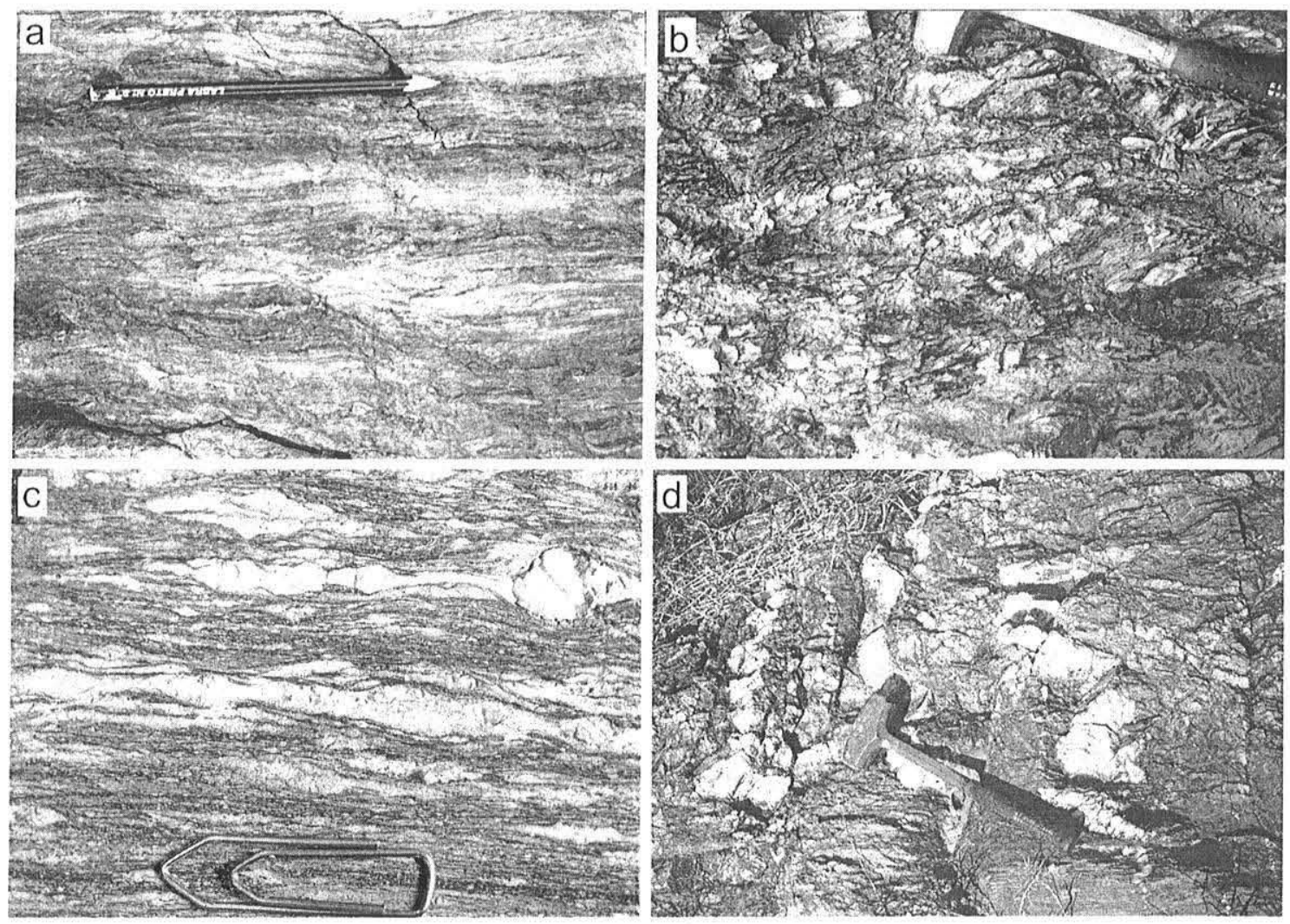

Figura 5 - Fotografias de feições de campo. (a) filonito, (b) brecha tectônica, (c) milonito com feições de cisalhamento ressaltadas pela presença de vênulas de quartzo estiradas e incorporadas à foliação, (d) filonito brechado cortado por veios de quartzo em várias direções (fraturamento hidiáulico).

reu intensa sericitização e recristalização dinâmica de quartzo.

Duas importantes inferências podem ser feitas a partir das relações entre o Maciço de Itaoca e a Zona de Cisalhamento Ribeira: (1) O truncamento pelo batólito das dobras e falhas que afetam o Subgrupo Lajeado indica que esse corpo é pós-tectônico em relação a pelo menos um evento tectônico; (2) O fato de o batólito encontrar-se cisalhado em sua porção sul e na mesma região apresentar xenólitos de rochas miloníticas associadas à zona de cisalhamento indica que esta se desenvolveu antes da intrusão do plúton e continuou ativa durante e após a sua instalação, evidenciando uma história evolutiva relativamente longa.

\section{Microestruturas e suas relações com a mineralogia metamórfica Cerca de 70 seções delgadas de rochas de falha da Zona de Cisalhamento Ribeira foram descritas em microscópio petrográfico convencional. As condições metamórficas da deformação foram avaliadas pelo reconhecimento de paragêneses metamórficas e pela análise qualitativa de microestruturas. A classificação das rochas de falha segue a nomenclatura de Sibson (1977). \\ Os diferentes litotipos identificados (rochas metasse- dimentares, metabasitos e rochas graníticas), são descritos detalhadamente abaixo.}

ROCHAS METASSEDIMENTARES Filito representa a rocha dominante no bloco a norte da zona de cisalhamento. Esta rocha é formada essencialmente por quartzo e sericita, que geralmente re- presentam de 70 a $90 \%$ em volume (Tabela 1). Clorita, carbonato e estilpnomelano geralmente são essenciais, podendo individualmente representar de 5 a 15\% em volume. Acessórios comuns compreendem turmalina, epidoto, biotita, titanita, minerais opacos, apatita e zircão. A biotita, quando presente, é essencialmente de natureza clástica.

Macroscopicamente o acamamento sedimentar representa a estrutura dominante. Ao microscópio observa-se uma laminação definida pela alternância entre leitos ricos em quartzo e leitos ricos em micas. Localmente, a orientação de micas clásticas e a presença de camadas ricas em minerais opacos definem uma laminação primária $\left(\mathrm{S}_{\mathrm{o}}\right.$ ). Esta é superposta por uma foliação metamórfica $\mathrm{S}_{1}$ constituída por uma xistosidade penetrativa com sericita, quartzo, muscovita, clorita, carbonato e estilpnomelano orientados sub- a paralelamente à laminação primária. Os minerais orientados nessa xistosidade apresentam-se dobrados e rompidos, desenhando uma crenulação $\mathrm{S}_{2}$ oblíqua que, em geral, não produz foliação penetrativa, mas localmente forma quartzo e sericita orientados em uma xistosidade espaçada (Fig. 6a).

A foliação $\mathrm{S}_{3}$ relaciona-se ao cisalhamento, sendo caracterizada por lenticularização de foliações anteriores e recristalização parcial ou total de sericita, quartzo, estilpnomelano, clorita e, localmente, biotita. Outros produtos compreendem foliação lenticularizada (Fig. 6b), texturas pisciformes (Fig. 6c) e estruturas SC (Lister \& Snoke 1984) e SC (Ramsay \& Lisle 2000) (Fig. 4c).

As rochas quartzosas ocorrentes no interior da zona de 
Tabela 1 - Proporções entre as fases minerais presentes em filitos e xistos. Siglas: Se, sericita; Qtz, Quartzo; Clt, clorita; Car; carbonato; Stp, estilpnomelano; Bt, biotita; Ep, epidoto; Tur; turmalina; Tit, titanita; Opa, minerais opacos; Gr; granada; Pl, plagioclásio: Mic, microclínio.

\begin{tabular}{|c|c|c|c|c|c|c|c|c|c|c|c|c|c|}
\hline Amostra & $\mathrm{Se}$ & Q1z & Clt & Car & Est & $\mathrm{Bt}$ & Ep & Tur & Tit & Opa & $\mathrm{Gr}$ & $\mathrm{Pl}$ & Mic \\
\hline $\mathrm{EP}()() / \mathrm{G}$ & 60 & 20 & - & - & 12 & - & - & $\mathrm{tr}$ & - & 8 & - & - & - \\
\hline F34D (1) & 20 & 30 & 05 & - & 5 & 40 & - & $\mathrm{tr}$ & - & $\mathrm{tr}$ & - & - & - \\
\hline $\mathrm{F} 35 \mathrm{~A}$ & 40 & 30 & 15 & 14 & - & - & - & 2 & $\mathrm{tr}$ & $\mathrm{tr}$ & - & - & - \\
\hline $\mathrm{F} 35 \mathrm{~B}$ & 40 & 35 & - & 15 & - & - & 5 & $\mathrm{tr}$ & 3 & 2 & - & - & - \\
\hline $\mathrm{F} 47$ & 40 & 50 & 10 & - & - & - & - & $\mathrm{tr}$ & - & $\mathrm{tr}$ & - & - & - \\
\hline GDI $21 \mathrm{~A} 1$ & 45 & 40 & - & - & - & - & - & 5 & - & 10 & - & - & - \\
\hline $\mathrm{GD} 121 \mathrm{~A} 2$ & 45 & 50 & - & - & - & 1 & - & 4 & - & $\mathrm{tr}$ & - & - & - \\
\hline $\mathrm{GD}|2| \mathrm{C}$ & 22 & 40 & - & 5 & 3 & - & - & $\mathrm{tr}$ & - & $\mathrm{tr}$ & - & 10 & 20 \\
\hline GD $121 \mathrm{E}$ & 50 & 30 & - & - & - & 5 & - & 8 & - & 7 & - & - & - \\
\hline GD $179 \mathrm{~B}$ & 35 & 50 & - & - & - & - & 15 & $\mathrm{tr}$ & - & $\mathrm{tr}$ & - & - & - \\
\hline IP132A & $\mathrm{tr}$ & 17 & 50 & 7 & - & - & - & - & - & 3 & $\mathrm{tr}$ & 13 & - \\
\hline IP530 & 35 & 20 & 25 & 15 & - & - & - & $\mathrm{tr}$ & - & 5 & - & - & - \\
\hline M()14 & 45 & 40 & $\mathrm{tr}$ & - & - & 10 & - & 1 & - & $\mathrm{tr}$ & 3 & - & - \\
\hline $\mathrm{M} 31 \mathrm{D}$ & $4 c$ & 5 & - & - & - & $\mathrm{tr}$ & - & 55 & - & $\mathrm{tr}$ & - & - & - \\
\hline$M 117$ & 40 & 5 & - & - & - & $\mathrm{tr}$ & - & 55 & - & $\mathrm{tr}$ & - & - & - \\
\hline M198 & 14 & 50 & $\mathrm{tr}$ & - & - & 25 & - & $\mathrm{tr}$ & - & 1 & 10 & $\mathrm{tr}$ & - \\
\hline $\mathrm{M} 2 \mathrm{I} 4 \mathrm{C}$ & 25 & 40 & $\mathrm{tr}$ & - & - & 27 & $\mathrm{tr}$ & 1 & - & 1 & 5 & $\mathrm{tr}$ & - \\
\hline
\end{tabular}

cisalhamento apresentam uma microestrutura na qual ribbons de quartzo com razões axiais variando de 7:1 a maiores que 2():1, ocorrem em meio a uma matriz formada por grãos de quartzo recristalizados dinamicamente (Fig. 6d). Na matriz os cristais de quartzo são levemente alongados, apresentam contatos retos a interlobados e encontram-se orientados numa direção levemente oblíqua à direção dos ribbons, caracterizando estruturas SC do tipo II de Lister \& Snoke (1984). A proporção de matriz recristalizada varia de 60 a $90 \% \mathrm{em}$ volume. Os ribbons de quartzo apresentam extinção ondulante, bandas e lamelas de deformação e subgrãos.

Nas faixas filloníticas a sericita apresenta-se lenticularizada e recristalizada na matriz milonítica, geralmente associada com clorita, estilpnomelano e localmente biotita. O carbonato ocorre disseminado na matriz recristalizada ou associado a vênulas estiradas e incorporadas à foliação milonítica.

Na faixa a sul da zona de cisalhamento é comum a presença de xisto de granulação média, laminado, com porfiroblastos de biotita e granada. A laminação é formada pela alternância entre leitos lepidoblásticos ricos em micas e leitos granoblásticos formados por quartzo poligonizado. Litotipos do Subgrupo Ribeira ocorrentes nessa faixa apresentam mineralogia essencial composta por quartzo, biotita, muscovita e granada. Minerais acessórios compreendem turmalina, minerais opacos, clorita, feldspato e epidoto.

O quartzo ocorre como grãos poligonais formando textura em mosaico de alto equilíbrio (contatos a $120^{\circ}$ ), dispostos em bandas muito contínuas alternadas com leitos micáceos (Fig. 7a). Provavelmente essa microestrutura está relacionada com recristalização estática (annealing).

Muscovita e biotita por vezes apresentam-se bastante estiradas e recristalizadas em leitos pobres em quartzo (Fig. 7a). O quartzo nesses leitos apresenta-se como ribbons policristalinos. Essas evidências indicam a natureza milonítica da foliação principal.

Ocorre biotita de quatro gerações. A mais antiga apresenta-se como finas inclusões em granada, orientadas em uma foliação externamente destruída. A biotita de segunda geração ocorre como porfiroblastos de micafish com inclusões de uma foliação retilínea discordante da externa, indicando que essa é pós-cinemática a uma fase tectônica. As formas lenticularizadas são decorrentes da

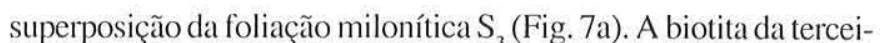
ra geração é mais fina, fortemente estirada e associada à muscovita nos leitos micáceos, sendo, portanto, sin-milonítica. A biotita de quarta geração ocorre em sombras de pressão na granada e a partir de substituição desta, indicando estar relacionada com retrometamorfismo.

A granada é dominantemente porfiroblástica e zonada. Seu núcleo apresenta inclusões de uma foliação retilínea com orientação divergente da foliação externa, correlacionável com aquelas encontradas na biotita de segunda geração (Fig. 7b), e sua borda apresenta-se limpa de inclusões indicando um sobrecrescimento provavelmente sin-milonítico. Localmente ocorre granada fina com formas lenticularizadas, cristalizada nos leitos ricos em quartzo, confirmando uma geração de granada sin-milonítica.

A clorita é retrometamórfica e ocorre como finas lamelas quase indistinguíveis ao microscópio petrográfico, formadas a partir de substituição das biotitas.

O epidoto, juntamente com biotita e mica branca, é decorrente da decomposição de granada, sendo, portanto, também retrometamórfico.

Na região de junção entre as zonas de cisalhamento Ribeira e Lancinha ocorrem corpos de xisto com granada, pertencentes à Sequiência Serra das Andorinhas, muito parecidos com aqueles pertencentes ao Subgrupo Ribeira a sul da Zona de Cisalhamento Ribeira, indicando que foram metamorfizados nas mesmas condições. São rochas formadas por muscovita, quartzo, biotita, granada, clorita, turmalina e minerais opacos. Uma diferença marcante observada, é a presença de planos de cisalhamento oblíquos à foliação $\mathrm{S}_{3}$, formando pares $\mathrm{SC}_{1}$ de Ramsay \& Lisle (2000).

Corpos tabulares de turmalinito xistoso milonítico, de ocorrência local, são caracterizados, no campo, por camadas negras de espessuras centimétricas, com foliação lenticularizada definida pela presença de aglomerados lenticulares de quartzo em meio a matriz muito fina de cor escura. Ao microscópio petrográfico essa rocha compreende além de turmalina, sericita, quartzo e muscovita. Foram descritas duas lâminas, cortadas segundo o plano $\mathrm{XZ}$ do elipsóide de deformação, representantes de rochas com graus de recristalização dinâmica contrastantes (milonito e ultramilonito). No milonito observa-se uma intensa foliação dada pela isorientação 

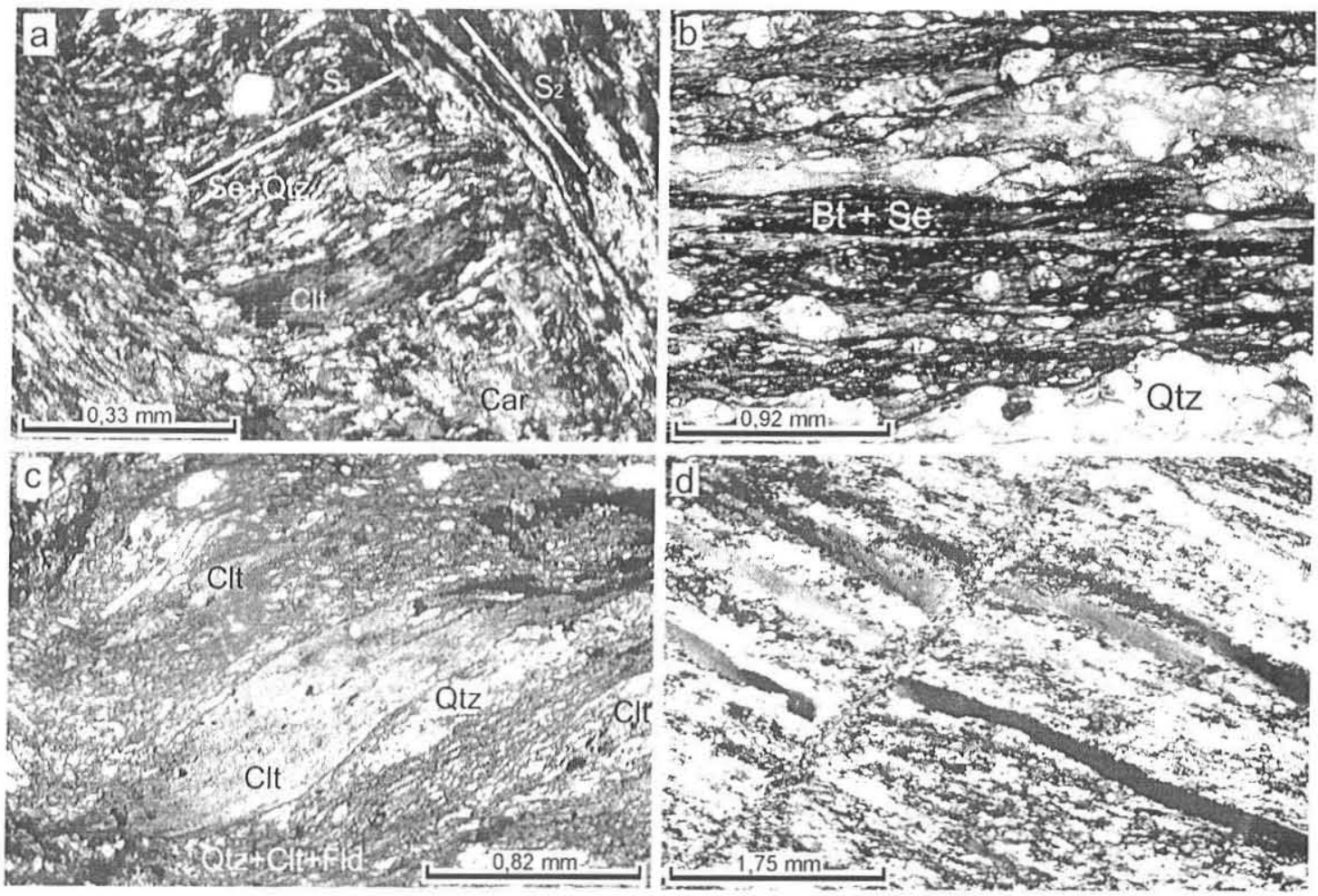

Figura 6 - Fotomicrografias de seções delgadas:( a) micróliton da foliação $S$, com clorita e muscovita, cortado pela $S$, com sericita, quartzo e carbonato, (b) foliação milonítica lenticularizada em biotita-quartzo-muscovita xisto milonítico,( c) clorita pisciforme em granada-feldspato-quartzo-clorita xisto milonítico, (d) ribbons monocristalinos de quartzo em meio a matriz recristalizada formada por quartzo poligonizado.

de sericita recristalizada. A turmalina disseminada junto com a sericita, ou em leitos distintos, é geralmente idiomórfica, com zoneamento de cores (castanho na borda e esverdeado no centro) e extinção ondulante, indicando deformação intracristalina. Apresenta-se dominantemente em corte perpendicular ao eixo-c. O quartzo na matriz encontra-se recristalizado. A diferença do ultramilonito é que neste caso a turmalina encontra-se recristalizada dinamicamente, por vezes com subgrãos internos e intensa extinção ondulante. Tanto no milonito quanto no ultramilonito ocorrem lâminas quartzosas com granulação mais grossa onde o quartzo encontrase poligonizado, formando texturas em mosaico com contatos retilíneos entre os grãos a aproximadamente $120^{\circ}$, indicando um alto equilíbrio contrastante com a matriz milonítica. A muscovita associada é idiomórfica e disposta em orientação aleatória. Localmente observam-se nesses leitos quartzosos duas gerações de quartzo, onde a mais antiga, em núcleos, apresenta granulação fina e intensa orientação preferencial de forma, e a mais nova, em bordas, é formada por grãos mais grossos e poligonizados, definindo texturas em mosaico. Essas evidências são indicativas de mecanismos de recristalização estática (annealing).

METABASITOS As rochas metabásicas consistem de corpos de anfibolito, xisto básico e clorita-plagioclásio-carbonato fels.

Os corpos de anfibolito ocorrentes a norte da zona de cisalhamento, quando pouco afetados por esta, apresentam-se geralmente isótropos, com estruturas ígneas preservadas (blastofíticas, blastosubofíticas). Os minerais essenciais são actinolita, epidoto e hornblenda (Tabela 2). A hornblenda é
Tabela 2 - Proporções entre as fases minerais presentes em metabasitos. Siglas: $\mathrm{Hb}$, hornblenda; Act, actinolita; Pl, plagioclásio; Ep, epidoto; Clt, clorita; Car, carbonato; Qtz. Quartzo; Opa, minerais opacos; Ap, apatita; Se, sericita.

\begin{tabular}{lcccccccccc}
\hline Amostra & $\mathrm{Hb}$ & $\mathrm{Act}$ & $\mathrm{Pl}$ & Ep & Clt & Car & Qt\% & Opat & Ap & $\mathrm{Se}$ \\
\hline F199B & 35 & 25 & 10 & 5 & 15 & 5 & 5 & tr & tr & - \\
GDI09A & 40 & 30 & 20 & 5 & - & - & tr & 5 & tr & - \\
GD177 & 10 & 50 & 20 & 15 & 5 & - & tr & tr & tr & - \\
GD486A & 15 & 45 & tr & 20 & 2 & - & 10 & 5 & 3 & - \\
GD487 & - & - & 8 & - & 30 & 20 & 30 & 10 & 2 & tr \\
GD532 & - & - & 10 & - & 15 & 50 & 5 & 8 & - & - \\
M1611 & 30 & $4(1)$ & 20 & 5 & - & - & tr & 5 & tr & - \\
\hline
\end{tabular}

idiomórfica, zonada, verde-acastanhada e em parte representa relíquias ígncass. A actinolita ocorre como poiquiloblastos orientados aleatoriamente na matriz.. O epidoto apresenta-se em agregados microcristalinos preservando formas reliquiares de plagioclásio tabular, arranjados aleatoriamente. Minerais acessórios compreendem quartzo, poiquiloblastos de minerais opacos, albita, apatita acicular e clorita.

Em posições mais próximas do interior da Zona de Cisalhamento Ribeira ocorrem corpos de xisto básico composto essencialmente por clorita, quartzo, carbonato, andesina e minerais opacos, além de apatita e sericita como acessórios (Tabela 2). Essas rochas apresentam um bandamento correlacionável com a foliação $\mathrm{S}_{3}$ das rochas metassedimentares, onde leitos carbonáticos alternam-se 
com leitos ricos em clorita e quartzo recristalizado. Internamente ao bandamento os minerais apresentam uma intensa orientação preferencial de forma. A andesina é de natureza ígnea e ocorre como porfiroclastos fraturados ou cristais idiomórficos ripiformes em meio a matriz fina composta por clorita e quartzo. Os minerais opacos encontram-se fortemente estirados, lenticularizados e com formas assimétricas indicativas de deformação rotacional. A sericita ocorre em sombras de pressão em porfiroclastos e como alteração de plagioclásio.

O clorita-plagioclásio-carbonato fels é isotrópo, possui estrutura ígnea parcialmente preservada, reconhecida pela presença de plagioclásio (andesina-labradorita) tabular ou ripiforme em orientação aleatória e quartzo intersticial. A matriz é muito fina e constituída por agregados microcristalinos de carbonato e clorita. Em geral a matriz representa de 50 a $65 \%$ em volume. Vênulas de carbonato e clorita cortam todas estruturas. Tais rochas são resultantes de metassomatismo de rochas básicas.

No interior da zona milonítica ocorrem corpos de anfibolito milonítico caracterizado por cristais de anfibólio lenticularizado envolto por matriz fina constituída por plagioclásio e hornblenda (Fig. 7c), além de acessórios como epidoto, apatita e minerais opacos. O anfibólio lenticularizado apresenta um zoneamento com actinolita no centro e hornblenda tschermackítica (dominante) nas bordas (Fig. 7d), indicando que a milonitização esteve associada a metamorfismo progressivo. Na matriz, o plagioclásio (An 35-45) encontra-se todo recristalizado dinamicamente indicando temperaturas de metamorfismo relativamente altas. Apresenta uma fraca orientação preferencial de forma e normalmente mostra geminação bem formada (Fig. 8a). A hornblenda na matrizé alongada e encontra-se disposta em orientação paralela à foliação lenticularizada (Fig. 8a). O epidoto ocorre como microcristais idiomórficos a subidiomórficos concentrados em certos leitos na matriz, porém. aparentemente, não está em paragênese com a hornblenda.

Ocorre localmente uma variação de anfibolito com estrutura brechada, constituído por anfibólio com zoneamento inverso àquele apresentado pelo anfibolito milonítico. Nesse caso predomina hornblenda tschermakítica no interior dos cristais e actinolita nas bordas, indicando fases retrometamórficas associadas ao cisalhamento. Outra diferença importante é dada pela grande proporção de clorita (15\%), mineral ausente no anfibolito milonítico. Os porfiroblastos de anfibólio podem estar brechados ou lenticularizados. A clorita encontra-se fortemente lenticularizada e pisciforme. Quartzo e plagioclásio são finos e recristalizados na matriz. O plagioclásio apresenta extinção concêntrica sugerindo zoneamentos composicionais. Epidoto microcristalino xenomórfico e carbonato ocorrem como acessórios. A estrutura é levemente orientada, onde leitos brechados ricos em anfibólio alternam-se com porções lenticularizadas formadas por clorita, plagioclásio, epidoto e quartzo. O carbonato ocorre também em vênulas estiradas cortando a foliação milonítica.

Os anfibolitos presentes a sul da faixa milonítica da Zona de Cisalhamento Ribeira apresentam características texturais e mineralógicas muito semelhantes àquelas dos corpos de anfibolito milonítico no interior da zona de cisalhamento. Uma diferença im-
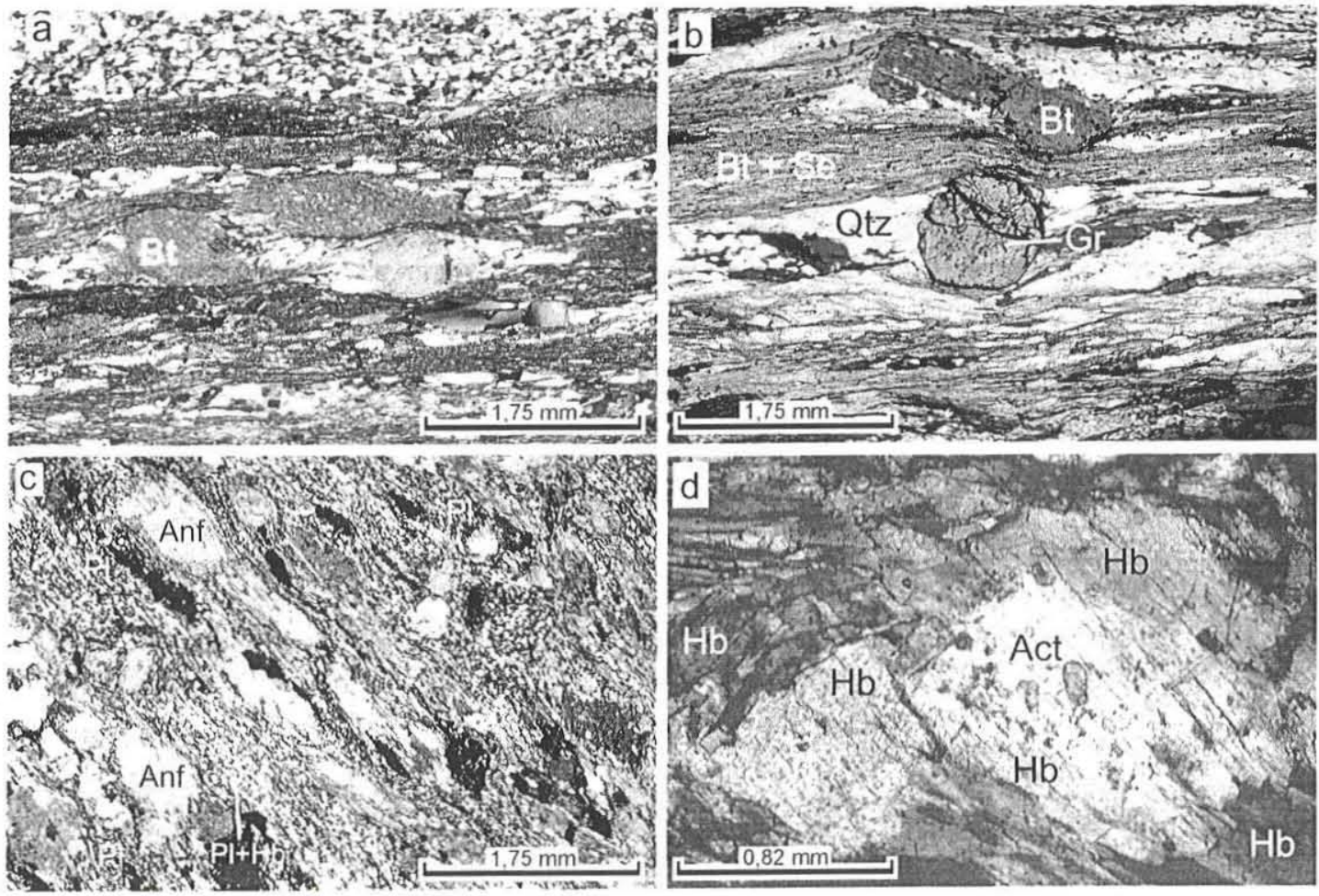

Figura 7 - Fotomicrografias de seções delgadas: a) porfiroclastos pisciformes de biotita de segunda geração em granadabiotita-muscovita-quartzo xisto do Subgrupo Ribeira, ( b) granada euédrica com inclusões orientadas em uma foliação retilínea anterior à $S_{r}$ (c) foliação lenticularizada milonítica definida por olhos de anfibólio em meio a uma matriz recristalizada constituída por plagioclásio, hornblenda e epidoto, em anfibolito milonítico, (d) anfibólio zonado formado por actinolita no centro e hornblenda na borda do cristal, 

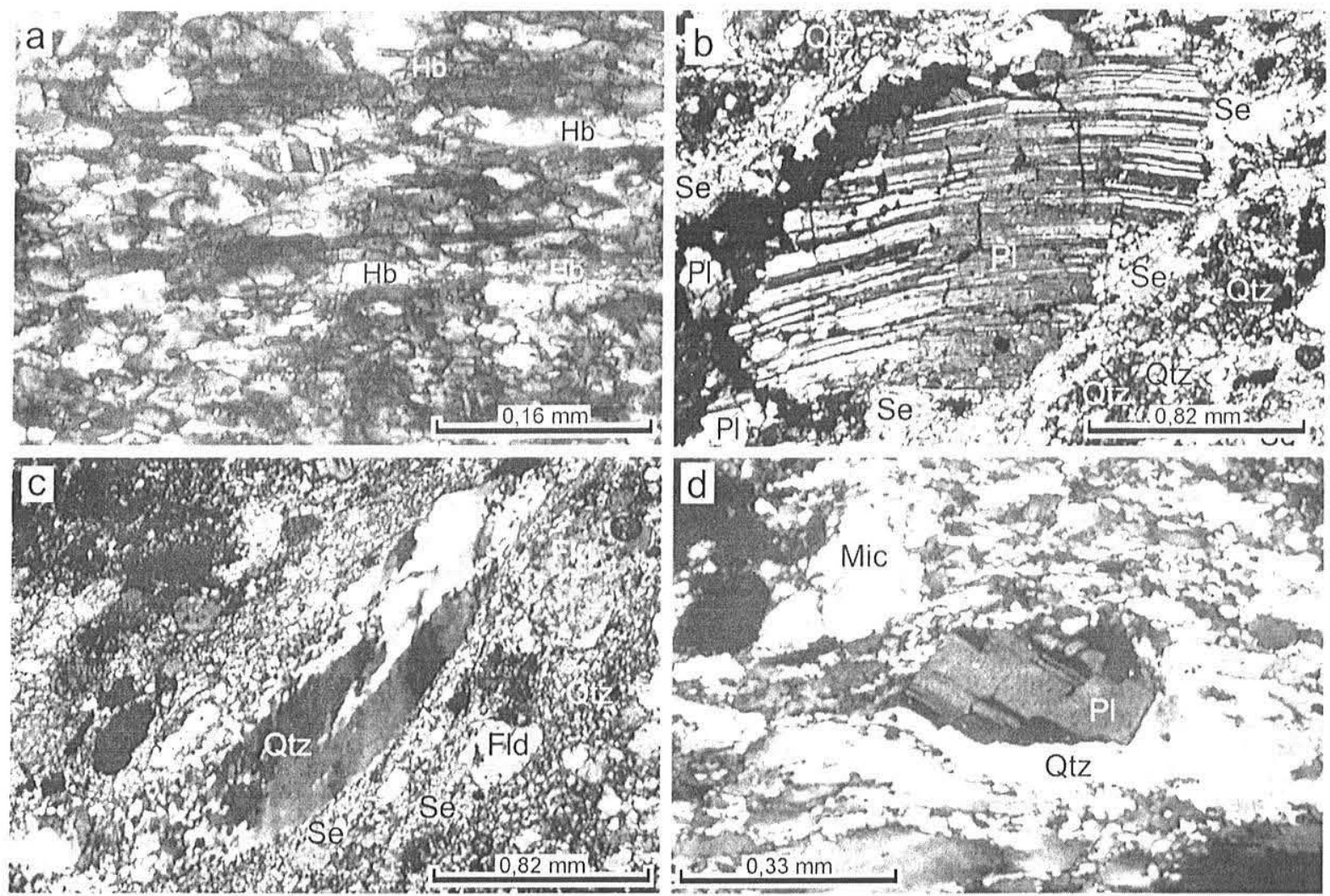

Figura 8-Fotomicrografias de seções delgadas: a) detalhe de matriz recristalizada formada por plagioclásio, hornblenda e epidoto em anfibolito milonítico, b) plagioclásio fraturado em meio a matriz formada por sericita e quartzo recristalizados em granito milonítico, c) ribbons de quartzo com borda parcialmente recristalizada em meio a matriz recristalizada constituída por sericita e quartzo em granito milonítico, d) veio quartzo-feldspático mostrando contraste entre deformação dúctil do quartzo e ríptil do plagioclásio.

portante é dada pela maior porcentagem de epidoto (15\%) e a presença de clorita (5\%), sugerindo condições metamórficas levemente menos intensas.

Um metabasito de ocorrência muito rara consiste de xisto porfiroblástico composto por clorita, quartzo, feldspato, biotita, minerais opacos e granada. A clorita é porfiroblástica, pisciforme e ocupa $50 \%$ da rocha. Quartzo e feldspato são microcristalinos e recristalizados na matriz. O feldspato apresenta formas arredondadas e extinção concêntrica, sugerindo zoneamentos composicionais. Os minerais opacos encontram-se fortemente estirados. A granada é euédrica, pós-cinemática à geração de uma foliação anterior à milonitização e encontra-se parcialmente substituída por biotita retrometamórfica. A clorita também pode ocorrer em sombras de pressão na granada, como resultado de retrometamorfismo. A estrutura dessa rocha consiste de um bandamento anastomosado formado pela alternância entre lâminas lepidoblásticas ricas em clorita e leitos granoblásticos constituídos por quartzo e feldspato. Como produtos do cisalhamento, a clorita e o quartzo encontram-se fortemente estirados, lenticularizados e com extinções ondulantes ou ainda recristalizados na matriz milonítica. A grande abundância de clorita $(50 \%)$ e feldspato $(15 \%)$ sugere que esta rocha pode ser de natureza originalmente vulcano-clástica, com contribuições básicas na deposição.

ROCHAS GRANÍTICAS As rochas graníticas deformadas pela
Zona de Cisalhamento Ribeira consistem de faixas alternadas de milonito, protomilonito, brecha e ultramilonito. Essas rochas apresentam como minerais essenciais quartzo, sericita, plagioclásio e microclínio. Acessórios compreendem clorita, estilpnomelano, biotita, epidoto, turmalina e zircão. Em algumas amostras o estilpnomelano, sempre associado com o cisalhamento, pode alcançar de 15 a $20 \%$ da rocha (Tabela 3 ).

Na brecha os feldspatos (microclínio e plagioclásio) são angulosos e encontram-se envolvidos por uma matriz arranjada caoticamente, composta por microcristais de quartzo, sericita e, por vezes, estilpnomelano. Os feldspatos apresentam extinção ondulante e kinks internos, denunciando deformações intracristalinas. No entanto, predominam microfraturas e microfalhas, indicando deformações principalmente por fluxo cataclástico (processo rúptil ativado pela fragmentação mecânica do mineral ou rocha acompanhado por subsequente deslizamento e rotação dos fragmentos (Passchier \& Trouw 1996)).

As rochas miloníticas (protomilonito e milonito) apresentam porfiroclastos lenticulares de feldspatos internamente fraturados, arqueados e falhados (Fig. 8b-d) em meio a uma matriz orientada, recristalizada dinamicamente. Esses minerais apresentam extinção ondulante e, localmente, subgrãos e grãos recristalizados nas bordas. A matriz é muito fina e formada por quartzo em grãos interlobados e sericita isorientada (Fig. 8b-d). O quartzo ocorre também como ribbons monocristalinos e policristalinos, exibindo extinção ondulante, bandas e lamelas de deformação, geralmente 
Tabela 3 - Proporções entre as fases minerais presentes em rochas graníticas. Siglas: Qtz. Quartzo: Pl, plagioclásio; Mic, microclínio; Se, sericita; Clt, clorita; Stp, estilpnomelano; Bt, biotita; Ep, epidoto: Tur; turmalina; Zir; zircão.

\begin{tabular}{lcccccccccc}
\hline Amostra & Qtz & Pl & Mic & Se & Clt & Est & Bt & Ep & Tur & Zir \\
\hline EP001B & 55 & 10 & 10 & 15 & 7 & - & - & - & 2 & tr \\
EP001E & 50 & 5 & 5 & 37 & - & 3 & - & - & tr & tr \\
EP001F & 15 & 20 & 20 & 30 & - & 15 & - & - & - & tr \\
F46A & 30 & 20 & 10 & 15 & - & 20 & 5 & tr & - & tr \\
F94 & 25 & 35 & 20 & 20 & - & - & - & - & - & tr \\
\hline
\end{tabular}

com bordas recristalizadas (Fig. 8d). A matriz se amolda em torno dos porfiroclastos definindo uma foliação anastomosada correlacionável com a $\mathrm{S}_{3}$ das rochas metassedimentares.

Faixas de ultramilonito ocorrem raramente e são caracterizadas por rochas onde raros porfiroclastos lenticularizados de feldspato, formados internamente por subgrãos e grãos poligonizados, são envoltos por matriz recristalizada muito fina composta por quartzo, feldspato e sericita. Uma forte orientação preferencial de forma desses minerais define a foliação milonítica.

METAMORFISMO De acordo com as paragêneses minerais as foliações $\mathrm{S}_{1}, \mathrm{~S}_{2}$ e $\mathrm{S}_{3}$ nas rochas metassedimentares ocorrentes na faixa norte da Zona de Cisalhamento Ribeira, foram geradas em condições de fácies xisto verde, geralmente na zona da clorita. A abundância de estruturas sedimentares primárias bem preservadas e a ocorrência local de cloritóide (identificados em campo), confirmam o metamorfismo na fácies xisto verde inferior. Segundo Bucher \& Frey (1994) o primeiro aparecimento da biotita em metapelitos geralmente ocorre em temperaturas ao redor de $400^{\circ} \mathrm{C}$, podendo se dar através da reação (1).

3 clorita +8 leldspato potássico $=5$ annita +3 muscovita + 9 quartzo $+4 \mathrm{H}, \mathrm{O} \quad$ (1)

A ausência generalizada de biotita metamórfica nas rochas ocorrentes a norte da Zona de Cisalhamento Ribeira sugere que o metamorfismo não ultrapassou os $400^{\circ} \mathrm{C}$ nesse domínio. De acordo com Bucher \& Frey (1994) o cloritóide pode ser o primeiro mineral metamórfico formado em "metapelitos normais" em temperaturas próximas a $300^{\circ} \mathrm{C}$. Como essa temperatura coincide com o início da recristalização dinâmica do quartzo, segundo Voll (1976), podemos inferir que as rochas miloníticas da faixa norte da zona de cisalhamento foram metamorfizadas entre $300^{\circ} \mathrm{e} 400^{\circ} \mathrm{C}$ (Fig. 9a).

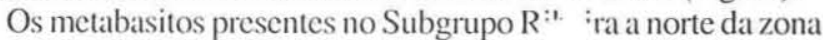
de cisalhamento apresentam a assembléia ac lita + epidoto + clorita \pm albita \pm quartzo \pm carbonato \pm hornblencia ígnea reliquiar. De acordo com Bucher \& Frey (1994) a assembléia č unostica do início da fácies xisto verde é dada pelo primeiro aparecimento de actinolita e epidoto na presença de clorita e pode ser formada ao redor de $28\left(0^{\circ} \mathrm{C}\right.$, abaixo de $3 \mathrm{kbar}$, pela reação (2) (Fig. 9b).

5 prehnita + clorita +2 quartzo $=4$ zoisita + tremolita $+6 \mathrm{H}_{2} \mathrm{O}(2)$

Entretanto, a mesma assembléia poderia ser gerada por reações envolvendo carbonatos, como por exemplo a reação (3).

3 clorita +10 carbonato +21 quartzo $=2$ zoisita +3 tremolita +

$$
10 \mathrm{CO}_{2}+8 \mathrm{H}_{2} \mathrm{O}(3)
$$

No caso analisado, não é rara a ocorrência de finas bordas de hornblenda na actinolita, sugerindo condições um pouco mais intensas de metamorfismo. Liou et al. (1974) determinaram que a partir de $475^{\circ} \mathrm{C}$ começa a instabilidade da clorita, que tende a reduzir seu volume na rocha com a progressão do metamorfismo. Le-
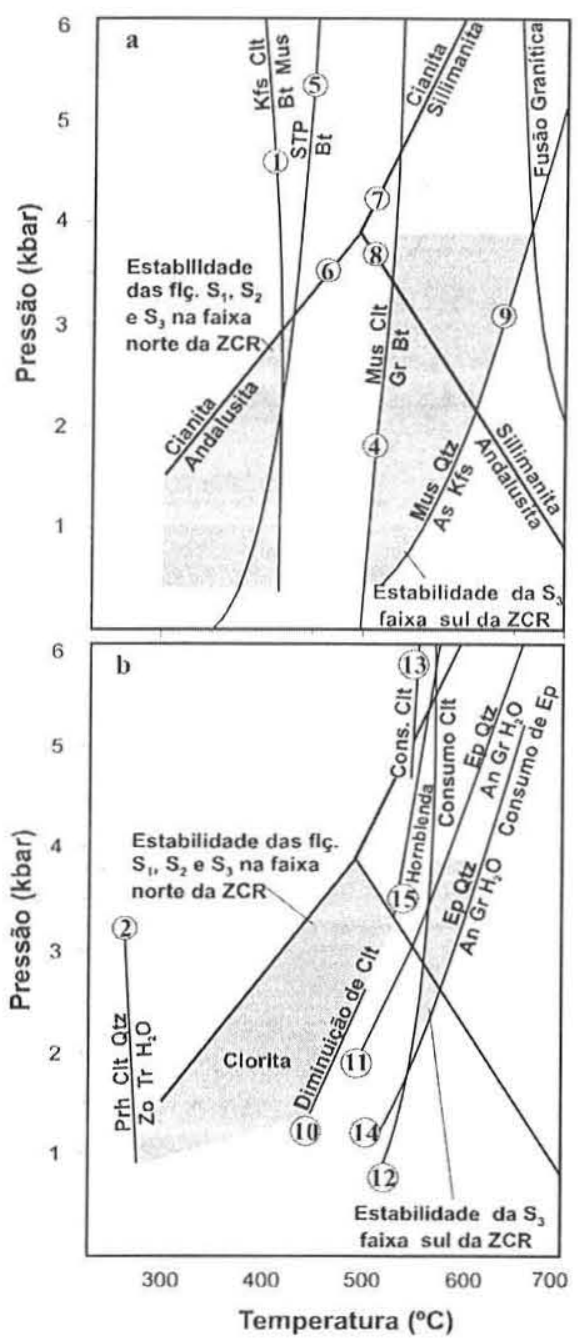

Figura 9 - Diagrama P versus T com reações metamórficas de: a) metapelitos (reações 1 e 4 segundo Bucher \& Frey (1994), reação 5 (consumo de estilpnomelano) segundo Winkler (1976), reações 6 a 9 segundo Spear (1993)); b) metabasitos (reação 2 segundo Bucher \& Frey (1994), reações 13 e 14 de Apted \& Liou (1983), reações 10 a 12 de Liou et al. (1974), reação 15 (produção de hornblenda) segundo Spear (1980)).

vando-se em conta que os metabasitos ocorrentes a norte da Zona de Cisalhamento Ribeira apresentam clorita estável, o metamorfismo não deve ter alcançado essa temperatura. Considerando as condições metamórficas apresentadas pelos corpos de filito relacionados, as paragêneses dos metabasitos são coerentes com metamorfismo em temperaturas entre $300^{\circ} \mathrm{e} 400^{\circ} \mathrm{C}$.

A paragênese típica dos xistos da faixa sul da Zona de Cisalhamento Ribeira quartzo + muscovita + biotita + granada, associada a ausência generalizada de clorita progressiva, sugere que a produção de biotita e granada se deu pela reação (4).

1 muscovita +3 clorita +3 quartzo $=4$ almandina +1 annita + $12 \mathrm{H}, \mathrm{O}(4)$

Segundo Bucher \& Frey (1994) essa reação limita a presença de clorita em rochas contendo excesso de muscovita e deve ocorrer entre $500^{\circ}$ e $520^{\circ} \mathrm{C}$. Esse intervalo pode ser considerado um limite mínimo de temperatura do metamorfismo que afetou as ro- 
chas miloníticas presentes nesse domínio.

Nas cercanias da Zona de Cisalhamento Ribeira as rochas de falha de ambos blocos tectônicos (norte e sul), separados por esta, apresentam diferentes intensidades de metamorfismo. No bloco norte a foliação milonítica $S_{3}$ apresenta geralmente recristalização de quartzo, sericita, clorita e estilpnomelano. Nas rochas do bloco sul foram recristalizados dinamicamente quartzo, muscovita, biotita e granada. Portanto, as paragêneses da foliação milonítica $S_{3}$ são idênticas àquelas apresentadas pelas foliações anteriores, em cada bloco.

A paragênese tshermackita + andesina (An 35-45) presente em anfibolito milonítico indica que o metamorfismo no interior da Zona de Cisalhamento Ribeira alcançou a fácies anfibolito. A presença de hornblenda e plagioclásio no início da fácies anfïbolito ocorre primeiramente em temperaturas ao redor de $500^{\circ} \mathrm{C}(e . g$. Bucher \& Frey 1994). A mesma reação contínua que produz a mineralogia inicial da fácies anfibolito, continua consumindo clorita e epidoto na fácies anfibolito inferior. Eventualmente a clorita desaparece em aproximadamente $550^{\circ} \mathrm{C}$ e o epidoto não é tipicamente encontrado em anfibolitos metamorfizados acima de $6000^{\circ} \mathrm{C}(\mathrm{Fig}$. 9b). Em pressões mais baixas o epidoto é todo consumido antes da clorita, enquanto em pressões mais altas ocorre o inverso (Fig. 9b). Condições de desaparecimento da clorita em rochas com composição basáltica foram determinadas experimentalmente em $550^{\circ} \mathrm{C} /$ $2 \mathrm{kbar}$ e $575^{\circ} \mathrm{C} / 5 \mathrm{kbar}$ (Liou et cl. 1974) e $525^{\circ} \mathrm{C} / 5 \mathrm{kbar}$ (Apted \& Liou 1983). Como o anfibolito milonítico apresenta pequenas quantidades de epidoto e clorita progressiva é ausente, a milonitização desta rocha deve ter ocorrido entre $550^{\circ}$ e $600^{\circ} \mathrm{C}$. Corrobora com essa interpretação a total recristalização dinâmica da andesina na matriz.

A deformação nas rochas graníticas afetadas pela Zona de Cisalhamento Ribeira ocorreu principalmente em condições de fácies xisto verde. De acordo com Voll (1976) os primeiros grãos de quartzo recristalizam-se em aproximadamente $300^{\circ} \mathrm{C}$. Com a progressão do metamorfismo o volume de grãos recristalizados deve aumentar constantemente. Como a porcentagem de quartzo recristalizado geralmente é grande (60-90\%), temperaturas maiores são sugeridas.

A presença de estilpnomelano em brechas e protomilonitos graníticos indica fases metamórficas provavelmente em temperaturas abaixo de $460^{\circ} \mathrm{C}$. Dados experimentais de Nitsch (1970) sugerem que a reação de consumo do estilpnomelano (5), está em equilíbrio em $445^{\circ} \mathrm{C} / 4 \mathrm{kbar}$ e $460^{\circ} \mathrm{C} / 7 \mathrm{kbar}$.

estilpnomelano + fengita $=$ biotita + clorita + quartzo $+\mathrm{H}_{2} \mathrm{O}(5)$

A aparente presença local de feldspatos parcialmente recristalizados (potássico e plagioclásio), poderia sugerir temperaturas em torno de $5000^{\circ} \mathrm{C}$ na milonitização, visto que o início da recristalização lestes minerais ocorre entre $480^{\circ}$ e $520^{\circ} \mathrm{C}$ (Voll 1980). No entanto, as microestruturas sugerem que a deformação desses minerais ocorreu principalmente por fluxo cataclástico, tornando pouco segura a interpretação de fases metamórficas ocorridas nesse intervalo de temperatura.

DISCUSSÃO E CONCLUSÕES Os dados paragenéticos e microestruturais permitem reconhecer uma evolução polifásica da Zona de Cisalhamento Ribeira, desde níveis francamente dúcteis associado a metamorfismo em condições de fácies anfibolito, até níveis relativamente rasos responsáveis pela geração de brecha tectônica em condições de fácies xisto verde. A longa história evolutiva fica bem registrada nas rochas do Maciço Itaoca, onde faixas de protomilonito e brecha granítica apresentam xenólitos de milonito e ultramilonito provenientes de rochas metassedimentares previamente deformadas.

Apesar do caráter polifásico da deformação é possível traçar um padrão de variação espacial, onde as rochas a norte dessa estrutura foram metamorfizadas em fácies xisto verde baixo, provavelmente entre $300^{\circ}$ e $400^{\circ} \mathrm{C}$, enquanto as rochas a sul foram metamorfizadas entre $500^{\circ}$ e $600^{\circ} \mathrm{C}$. As paragêneses da foliação milonítica $\left(\mathrm{S}_{3}\right)$ mostram-se idênticas àquelas das foliações anteriores presentes nas rochas de ambos os blocos, norte e sul, sugerindo que a Zona de Cisalhamento Ribeira foi responsável pela justaposição de rochas de diferentes níveis crustais através de um rejeito vertical importante. Uma mudança estrutural acompanha essa variação metamórfica. Enquanto no bloco norte a estrutura dominante é um acamamento primário, além de estarem preservadas duas foliações metamórficas pré-cisalhamento, nas rochas do bloco sul existe apenas uma foliação externa correlacionável com a milonítica $\left(\mathrm{S}_{3}\right)$ e uma foliação externamente destruída preservada apenas como inclusões orientadas em cristais pré-cisalhamento de granada e biotita. Esse padrão pode facilmente ser explicado pela própria transcorrência. Considerando-se o rejeito direcional horário ao redor de $50 \mathrm{~km}$ calculado por Campanha \& Sadowski (20)2), com uma lineação de estiramento caindo entre $4^{\circ}$ e $5^{\circ}$ para nordeste teríamos um rejeito vertical entre 3,5 e 4,4 km. Esse rejeito vertical deve ser o responsável pelo salto de, no mínimo, $100^{\circ} \mathrm{C}$ entre o metamorfismo dos blocos tectônicos limitados pela Zona de Cisalhamento Ribeira (Fig. 10).

A rocha que apresentou o mais alto grau metamórfico (determinado pela petrografia) foi um anfibolito situado no interior da zona de cisalhamento. Nessa rocha a paragênese hornblenda + andesina (An 35-45), associada à completa ausência de clorita e a total recristalização dinâmica do plagioclásio, sugere condições metamórficas entre $550^{\circ} \mathrm{e} 600^{\circ} \mathrm{C}$, estando, portando, ligeiramente acima das condições de temperatura apresentadas pelas rochas encaixantes. A presença de porfiroclastos de anfibólio com núcleo de actinolita e borda de hornblenda e de hornblenda recristalizada na matriz milonítica indica que a milonitização se

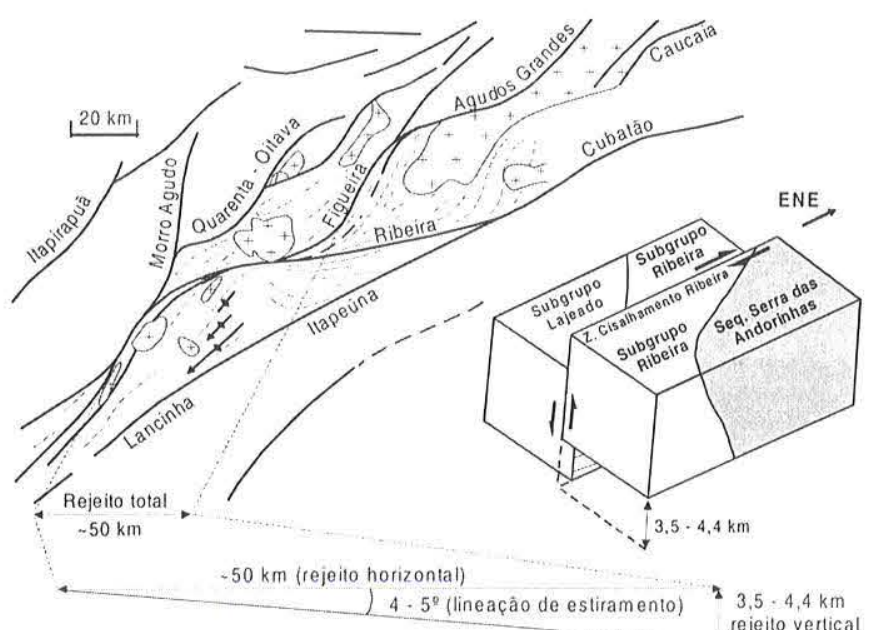

Figura 10 - Interpretação cinemática da Zona de Cisalhamento Ribeira a partir de dados metamórficos e geométricos. 
deu, num dado momento, com aumento da temperatura.

As paragêneses metamórficas presentes nas rochas metassedimentares não são conclusivas em termos de pressão. Entretanto, a ausência generalizada de cianita, mesmo em rochas que aparentemente teriam composições adequadas para a formação desta, sugere valores de pressão inferiores a 4 kbar, considerando as reações dos polimórfos de $\mathrm{Al}_{2} \mathrm{SiO}_{5}$ atualmente mais aceitas na bibliografia (e.g. Spear 1993, Bucher \& Frey 1994). As paragêneses do anfibolito milonítico presente no interior da zona de cisalhamento, sugerem pressão mínima entre 2 e 3 kbar, consi- derando as interseções entre as reações de consumo de clorita e epidoto (Fig. 9b). Estimativas de $500^{\circ}-550^{\circ} \mathrm{C}$ e 2-2,6 kbar para o aprisionamento de inclusões fluidas sin-miloníticas em veios de quartzo cisalhados (Faleiros \& Campanha 2003) confirmam uma deformação tipicamente de baixa pressão.

Agradecimentos À FAPESP pelo suporte financeiro da bolsa de mestrado concedida ao primeiro autor (processo 01/00199-4), e pelo auxílio à pesquisa relativo ao processo $96 / 5648-1$. Aos relatores da RBG pelas sugestões ao manuscrito.

\section{Referências}

Apted M.J. \& Liou J.G. 1983. Phase relations among greenshist, epidoteamphibolite, and amphibolite in a basaltic system. Am. J. Sci., 283:328353

Bucher K. \& Frey M. 1994. Petrogenesis of metumorphic rocks. SpringerVelag, $318 \mathrm{p}$.

Campanha G.A.C. 1991. Tectônica proterozóica no Alto e Médio Vale do Ribeira, Estados cle São Paulo e Paraná. Tese de Doutorado, Instituto de Geociências, Universidade de São Paulo, 296 p., anexos.

Campanha G.A.C. \& Sadowski G.R. 1999. Tectonics of the Southern Portion of the Ribeira Belt (Apiaí Domain). Prec. Res., 98:31-51.

Campanha G.A.C. \& Sadowski G.R. 2002. Determinações da deformação finita em rochas metassedimentares da Faixa Ribeira na região de Iporanga e Apiaí, SP. Rev. Bras. Geoc. 32:639-650.

Campanha G.A.C., Gimenez Filho A., Caetano S.L.V., Pires F.A., Dantas A.S.L., Teixeira A.L., Dehira L.K. 1985. Geologia das follas Iporanga (SG.22-X-B-V-2) e Gruta do Diabo (SG.22-X-B-VI-1). Estado de São Paulo. São Paulo, IPT/Pró-Minério, Relatório 22352.

Campanha G.A.C., Gimenez Filho A., Caetano S.L.V., Pires F.A., Dantas A.S.L., Teixeira A.L., Dehira L.K. 1986. Geologia e estratigrafia da região das folhas Iporanga e Gruta do Diabo, Vale do Ribeira, São Paulo. In: SBG, Cong. Bras. Geol., 34, Goiânia, Anciis, v.2, pp.: 1058 1073.

Faleiros F.M. 2003. Zona de Cisalhamento Ribeira: deformação, metamorfismo e termobarometria de veios sin-tectônicos. Dissertação de Mestrado, Instituto de Geociências, Universidade de São Paulo, $146 \mathrm{p}$.

Faleiros F.M. \& Campanha G.A.C. 2003. Evolução metamórfica da Zona de Cisalhamento Ribeira, Vale do Ribeira, SP e PR: Evidências de microestruturas, tramas de eixos-c de quartzo e inclusões fluidas. $I n$ : SBG, Simp. Geol. Sudeste, 8, Atas, p. 17.

Faleiros F.M.. Campanha G.A.C.. Bello R.M.S. Fuzikawa K. P-T conditions and fluid evolution during growth and deformation of strike-slip fault-related veins, Ribeira Shear Zone, SE-Brazil. (em preparação).

Liou J.G., Kuniyoshi S., Ito K. 1974. Experimental studies of the phase relations between greenschist and amphibolite in a basaltic system. Am. J. Sci., 274:613-632.
Lister G.S. \& Snoke A.W. 1984. S-C Mylonites. J. Struct. Geol., 6:617638.

Mello I.S. 1995. Geologia e aspectos metalogenéticos do Maciço Itaoca. Vale do Ribeira. SP e PR. Tese de Doutorado. Instituto de Geociências, Universidade de São Paulo, 168p.

Mello I.S. \& Bettencourt J.S. 1998. Geologia e gênese das mineralizações associadas ao maciço de Itaoca, Vale do Ribeira, SPe PR. Revi. Bras. Geoc., 28:269-284.

Nitsch K.H. 1970. Experimentelle Bestimmung der oberen Stabilitätsgrenze von Stilpnomelan. Forstschr Mineral 47, Beih 1:4849.

Passchier C.W. \& Trouw R.A.J. 1996. Microtectonics. Berlim Heidelberg, Springer-Verlag, 289p.

Ramsay J.G. \& Lisle R.J. 2000. The techniques of modern structural geology. Volume 3: Applications of Continum Mechanics in Structural Geology. Academic Press, London 560 p.

Sibson R. H. 1977. Fault rocks and fault mechanisms. J. Geol. Soc. London 133:191-213.

Spear F. 1980., NaSi-CaAl exchange equilibrium between plagioclase and amphibole. Contrib. Mineral. Petrol., 72 (1):33-41.

Spear F. S. 1993. Metamorphic phase equilibria and pressure-temperaturetime paths. Mineralogical Society of America. Monograph. 799p.

Voll G. 1976. Recristallization of quartz, biotite and feldspars from Ersfeld to the Leventina nappe, Swiss Alps, and its geological significance. Schweiz Mineral. Petrogr. Mitt. 56:641-647.

Voll G. 1980. Ein Querprofil surch die Schweizer Alpen von Vierwaldstaetter See zur Wurzelzone - Strukturen und ihre Entwicklung durch Deformationsmechanismen wichtinger Mineral. N. Jb. Geol. Palaeont. Abh 160:321-335.

Winkler H.G.F. 1976. Petrogenesis of Metamorphic Rocks. SpringerVerlag, New York.

Manuscrito A-1451

Recebido em 23 de julho de 2003

Revisão dos autores em 27 de abril de 2004 Revisão aceita em15 de maio de 2004 